\title{
Call for Special Issue Papers: Sustainability and Environmental Justice under Neoliberalism-Sites of Resistance and Acceptance
}

\author{
Deadline for Manuscript Submission: August 31, 2021 \\ Guest Editors: Stephanie Malin, PhD; Colorado State University, Fort Collins, Colorado, USA; \\ Jill Lindsey Harrison, PhD; University of Colorado-Boulder, Boulder, Colorado, USA; \\ David Ciplet, PhD; University of Colorado-Boulder, Boulder, Colorado, USA
}

As societies contend with multiple socioecological crises such as climate change and COVID-19, we have an opportunity to build more just, democratic, and sustainable economic, political, and technological systems. Yet, in the last 40 years, neoliberal capitalism's cultural and institutional influence have shaped the present moment in powerful ways. Neoliberalism refers to a globally dominant system of ideologies, narratives, programs, and policies that privilege free markets and trade, advocate for privatizing public resources, deregulate and reregulate environmental and other rules, and shrink social safety nets. As such, it works against the prospects for just transitions. The internalization and institutionalization of market-based thinking erect significant barriers to meaningful and transformative social change around climate justice and other environmental justice issues.

Environmental justice activism has often challenged neoliberalism; these "sites of resistance" help to transform systems of power. However, many actors in environmental politics have succumbed to market pressures and even internalized neoliberal norms, contributing to "sites of acceptance" to risky industrial activities and undermining environmental justice practices and tenets within civil society, regulatory institutions, and policy contexts.

Actors within sites of acceptance mobilize to support risky industrial activities such as mining, milling, and oil and gas production; reject large-scale environmental regulations and support corporate self-regulation; and oppose efforts to draw down atmospheric greenhouse gases and otherwise support climate justice. In the name of efficiency, marketization, and urgency, individuals and institutions comprising sites of acceptance also accept or embrace top-down and non-inclusive policy processes and those that neglect considerations of equity and justice. In the process, environmental politics often reproduce systems of privilege and inequality, further disempowering marginalized communities that are disproportionately impacted by polluting industries and a changing climate.

Thus, environmental activism can usher in transformative changes to neoliberal structures of power, or alternatively, it can serve to solidify and stabilize hegemonic neoliberal structures and conditions of governance - and reproduce or deepen inequality experienced by marginalized communities. This special issue is designed to create an opportunity wherein scholars can analyze the role of distinct social responses to sustainability and environmental justice in the context of neoliberalism.

We invite research that examines these issues from three different perspectives:

1) Investigations of "sites of acceptance," the role of neoliberal norms in driving them, and the challenges they may create for activists pursuing climate and environmental justice and transitions to more socially just systems;

2) Investigations of "sites of resistance" that offer examples of important counters to neoliberal systems and illustrate their transformative potential as a result;

Mary Ann Liebert, Inc., publishers, 140 Huguenot Street, New Rochelle, NY 10801, USA. 
3) Empirically grounded conceptual or theoretical contributions that may guide transformative social or political responses for a just transition in neoliberal contexts.

Submission Deadline: All manuscripts should be submitted for consideration by August 31, 2021.

All manuscripts should be submitted online using Manuscript Central (https://mc.manuscriptcentral.com/ environmentaljustice) by August 31, 2021. All submissions will be subject to a rigorous peer review. We encourage submissions of original research articles, reviews, and perspectives. Please review our Instructions for Authors at www.liebertpub.com/env for more information.

\section{Visit the Instructions for Authors:}

www.liebertpub.com/env

Submit your paper for peer review online:

https://mc.manuscriptcentral.com/environmentaljustice 